\title{
微生物嘰能を用いたPCB無害化処理システムの開発
}

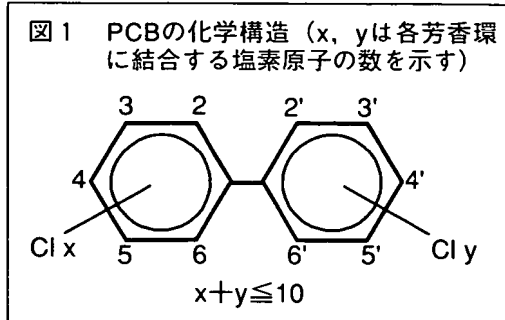

図 2 PCB処理システムの概略

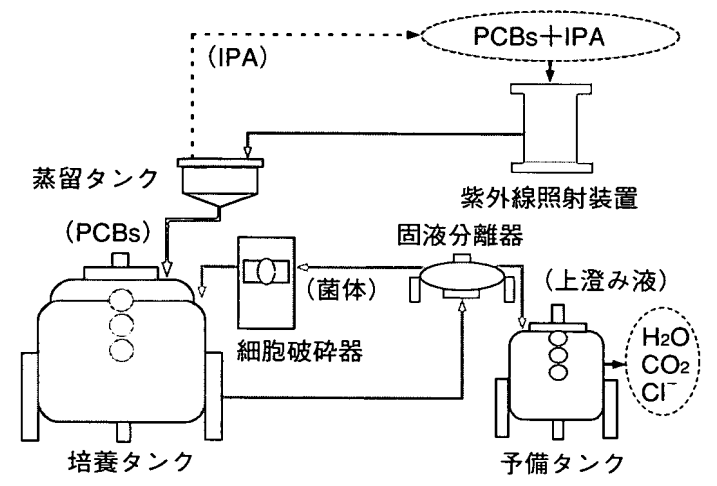

図 3 実証試駼結果の概要

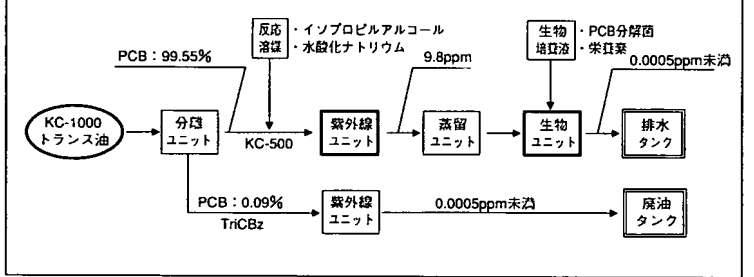
た.

の確保とパブリックアクセプタン スの獲得が課題となる.われわれ は常温・常圧反応による安全な無 害化処理を重視し, 微生物処理に よるPCB無害化プロセスを確立し

\section{口本処理法の対象と 構成}

本法はPCB油が処理 対象であり，PCBを含 有する污染物の場合, 何らかの方法でPCBを 分離することで対応す る. パイロット装置の 概略を図 2 に示した。 工程は紫外線処理工程 と微生物処理工程に大 別される. 紫外線処理 ではPCBの部分的脱塩 素を行い, 微生物処理 により完全分解を行っ ている.

\section{裝置構成とプロセス} 紫外線処理 $\mathrm{PCB}$ 油は, イソプロピルア ルコール（IPA）と混 合し, 紫外線照射工二

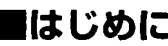

PCB (Polychlorinated biphenyl, 図 1 ）は, 今から30年ほど前まで 使用されていた塩素化芳香族化合 物であり，カネミ油症事件の原因 物質として知られている.2001年, PCB処理特別措置法が制定され， 国内のすべてのPCBを15年以内に 処理することが決まった。また， これに先立ち一部の企業では, 自 社で保管しているPCBの処理が実 施されている. 鉄道分野でも車両 搭載主変圧器などPCB使用機器が 存在することから, 独自にPCB処 理技術の開発を進めてきた.

既存のPCB処理技術は反応効率 が良い反面, 熱・圧力・高反応性 化学物質を使用するため, 安全性
ットに送られる. IPAはPCB濃度 の調整および脱塩素反応における 電子供与体としての機能をもつ. 紫外線のエネルギーにより, 芳香 環上の塩素 - 炭素結合が解離され, 脱塩素反応が起こる。ささらに，脱 塩素によって生じたラジカル種が IPAを介して新たな脱塩素反応を 引き起こす．この連鎖反応により 効率よく脱塩素が進行する。しか し, 反応生成物が蓄積するため, ラジカル捕捉や紫外線の遮蔽・競 合的吸収の割合が増大する。した がって, 紫外線処理によるPCBの 完全無害化を実現するためには， 反応生成物を除去する付帯設備が 必要になる。われわれは紫外線処 理をPCBの塩素削減工程と位置つ
けることで, 紫外線ユニットの簡 素化を図っている．照射後のPCB 溶液からIPAを分離回収し, 生成 した低塩素化PCBとビフェニル （完全脱塩素物）を微生物処理槽に 移送する。回収したIPAは中和反 応で生成した $\mathrm{NaCl}$ を分離した後, 紫外線照射に再利用している。

微生物処理使用するPCB分 解細菌は, われわれ独自の菌株で あり, 他の菌株では生存できない PCB濃度環境下でも, $\mathrm{PCB}$ の代謝 機能を維持できる。PCBの代謝反 応には酸素が不可欠であるため, タンク内には曝気と攪拌を行って いる. PCBと共に培養タンク（培 養量 $1000 \mathrm{~L}$ ）に投入されたビフェ ニルは, 菌のエネルギー源になる. 所定時間処理した後に, 槽内の培 養液の $30 \%$ 相当量を取りだし新た な紫外線処理済PCBと水を加える ことで運転を連続化している，固 液分離装置を用いて回収した菌体 は, 連続式細胞破砕装置を経由し た後, 微生物タンクに戻すことで 栄養源として再利用している。排 水のPCB処分基準は $0.003 \mathrm{mg} / \mathrm{L}$ (ppm) であり, これ以下であるこ とを確認した後，排出する.図 3 に試験の結果の一例を示した。

\section{おわりに}

廃呆物処理法の規定により, PCB処理には国が認可した技術以 外は使用できない。本技術は2000 年9月にPCB処理法として官報に記 載され，正式に認可を得ている。 微生物を用いたPCB処理法の実用 レベルでの確立は世界でも初の事 例である. 今後は, 本技術を基に PCB污染土壌などの污染物浄化技 術を開発したいと考えている。 (原稿受付 2002年2月25日) 〔早川敏雄, 金原和秀

（財）鉄道総合技術研究所] 